\title{
Determination of quality and quantity of DNA template using modified CTAB protocol
}

\begin{abstract}
DNA extraction protocol on Jatropha plant needs to be modifying in order to obtain good template DNA for PCR amplification. Total DNA was extracted using modified CTAB extraction protocol. This modify protocol provided enough quantities and quality of DNA for PCR amplification that produced $\sim 530 \mathrm{bp}$ PCR product. It indicated that Dry leaves samples has high DNA quantity than the fresh samples, but they are almost at the same quality which confirmed by Spectrophotometer.
\end{abstract}

Keywords: DNA, genome, jatropha, mosaic viruses, medicinal plant, CTAB
Volume 4 Issue 5 - 2019

\author{
Abdullahi M,' Bello I,' Ahmad M,' \\ Abdurrahman SA,' Idris M,' MA Garga,' \\ Tanimu A Tagago, 'Maruthi MN, ${ }^{2}$ Seal SE, ${ }^{2}$ \\ Abarshi MM $^{3}$ \\ 'National Biotechnology Development Agency, Bioresources \\ Development Centre, Nigeria \\ ${ }^{2}$ Natural Resource Institute (NRI), University of Greenwich, UK \\ ${ }^{3}$ Department of Biochemistry Ahmadu University Zaria, Nigeria
}

\author{
Correspondence: Abdullahi Mohammad, National \\ Biotechnology Development Agency, Bioresource Development \\ Centre, P. M. B. 2140 Katsina, Katsina State, Nigeria, Tel \\ +2348I62784144, Email abdullahbyI I@gmail.com
}

Received:September 19,2019 | Published: October 14, 2019

\section{Introduction}

Jatropha (Jatropha curcas) is one of the 170 known species that belongs to the family Euphorbiaceae. ${ }^{1}$ Jatropha is a small shrub tree which has pale-green leaves and produces latex when the plant is cut. ${ }^{1}$ Jatropha plant derives its name from the Greek word iatros (doctor) and trophe (food) which indicates the plant's medicinal value in ancient times. ${ }^{1}$ The species name 'curcas' comes from the name physic nut found in Malabor, India. ${ }^{1}$ Jatropha plant grows to a height of up about 3-5 meters, but under favourable agronomic conditions it grows up to $8-10$ meters. $^{2}$

Jatropha curcas can be found in tropical and subtropical regions and it can also grow in drought conditions although jatropha yields better under irrigated cultivation. ${ }^{2}$ For many years scientists attempted to identify the origin of Jatropha plant but the sources are still controversial. ${ }^{1}$ Martin et al., ${ }^{3}$ reported that jatropha originated from Ceara state of Brazil, and Dehgan et al., ${ }^{4}$ supported this by reporting the Mexico and Central America are the likely to be origin of the Physic nut (Jatropha). ${ }^{1}$ Today jatropha is found worldwide, especially in developing countries (Centre for Jatropha Promotion 2007). In the last decade the cultivation of jatropha increased dramatically because of its importance as its seeds serve as raw material for biofuel synthesis. ${ }^{2}$ When compared to other crops that are used in biofuel productions jatropha produces the maximum yield; for example from corn 200 barrels of biofuel can be used per square mile area per year in USA, rice can produce 1000 barrels and Jatropha produces up to 2000 barrels of oil per square mile in a year.

However jatropha is also useful as a source of organic manure, medicinal plant, lubricant and used in soap making. J. curcas was also found in Nigeria especially in the rural areas as hedge plants to demarcate farm boundaries and to protect crops against invasive wild and domestic animals. Only recently with the development of biofuel industry jatropha is being used as a source of income in Nigeria. ${ }^{5}$
Today Jatropha is cultivated intensively in many developed and developing countries which have lead to increased number of pests and diseases being affecting the plant including begomoviruses which cause Jatropha mosaic disease (JMD). JMD was first reported from Puerto Rico on Jatropha gossipiifolia and it was also present in Jamaica, Mexico, Mali, Cuba and America. ${ }^{6}$ Furthermore JMD was also reported in 2004 from India, and is associated with Jatropha mosaic Indian virus (JMIV), which is transmitted, by Bemisia tabaci. ${ }^{7,8}$ Based on sequencing of the partial genome of JMIV, it confirmed that it's closely related to cassava mosaic viruses infecting cassava in India. ${ }^{8}$ However, the precise taxonomic position of the virus (JMIV) could not be confirmed because of the limited data available, which requires an immediate investigation consider the global importance of the crop. ${ }^{7}$

\section{Methodology}

\section{Protocol for DNA extraction from the infected leaves samples}

Total DNA was extracted from the infected Jatropha leaves sample, using CTAB method according to Lodhi et al., ${ }^{9}$ which modified by $\mathrm{Dr}$ Maruthi of the NRI University of Greenwich.

Step 1: Leaves samples of Jatropha plant were collected out of freezer at $-80^{\circ} \mathrm{C}$; about $0.1 \mathrm{~g}(100 \mathrm{mg})$ of the disease plant was placed into a thick gauged plastic bag.

Step 2: The plant tissues were grounded with the used of roller and mixed with 10 volumes $(1 \mathrm{ml})$ of the CTAB extraction buffer.

Step 3: About $750 \mu 1$ of each sample was poured in to $1.5 \mathrm{ml}$ eppendorf tube, the samples were then heated at $60^{\circ} \mathrm{C}$ for $30 \mathrm{~min}$.

Step 4: The samples were mixed with an equal volume of $(750 \mu 1)$ of phenol:chloroform:isoamylalcohol (1:24:1) and mixed gently to form an emulsion, then centrifuged at $13000 \mathrm{rpm}$ for about $10 \mathrm{~min}$. 
Step 5: The top aqueous phase was transferred in to $1.5 \mathrm{ml}$ eppendorf tubes with the used of wide bore pipette tips ( $1 \mathrm{ml}$ tips).

Step 6: The DNA samples were precipitated by adding 0.6 volume $(300 \mu \mathrm{l})$ of cold $\left(-20^{\circ} \mathrm{C}\right)$ isopropanol and incubated at $-20^{\circ} \mathrm{C}$ for at least $1 \mathrm{hr}$. The samples solution was be kept at $-20^{\circ} \mathrm{C}$ weeks.

Step 7: The samples were collected from freeze $\left(-20^{\circ} \mathrm{C}\right)$, and centrifuged at $13000 \mathrm{rpm}$ at $4^{\circ} \mathrm{C}$ for about $10 \mathrm{~min}$ and the supernatant was discarded.

Step 8: The pellet was washed in $0.5 \mathrm{ml} 70 \%$ ethanol by vortexing and then centrifuged for about $5 \mathrm{~min}$ at $13000 \mathrm{rpm}$.

Step 9: The ethanol was removed and the pellet was vacuum to dry for $5 \mathrm{~min}$. The dried pellet was suspended in $100 \mu 11 \mathrm{x}$ TE buffer and stored at $-20^{\circ} \mathrm{C}$.

\section{Results and discussion}

Total DNA was extracted from the Jatropha Plant sample which shows mosaic symptoms using CTAB method ${ }^{9}$ which modified at Natural Resources Instituted University of Greenwich UK. This modified CTAB method provides enough quantity and quality of DNAs, for PCR amplification which confirm by Spectrophotometer at absorbance mean A260/A280.

DNA qualities of the fresh and dry samples (Tables 1\&2).

Table I The above result of DNA purity indicates that the samples are of good quantity. Normally a good DNA template quantity should be above $200 \mathrm{ug} / \mathrm{ml}$. In the above result only sample 2 and 6 have less DNA quantity but they are of good quantity to produce PCR amplicons. However the Spectrophotometer result above indicate that Dry leaves samples were of high DNA quantity with the average mean 492.1 ug/ml, than the fresh samples with average mean of $257.6 \mathrm{ug} / \mathrm{ml}$

\begin{tabular}{lcc}
\hline JMIV & Fresh ug/ml & Dry ug/ml \\
\hline Sample I & 312.6 & 420.1 \\
Sample 2 & 172.9 & 236.3 \\
& & \\
Sample 3 & 384 & 851.8 \\
& & \\
Sample 4 & 160.9 & 460.2 \\
\hline
\end{tabular}

Table 2 The above result of DNA purity indicates that the samples are of good quality. Normally a good DNA template quality has reading in between $\sim 1.8$ absorbance ratios A260/280. The absorbance ratios were between 1.85 to 2.7 shows that DNA samples are of good purity

\begin{tabular}{lll}
\hline JMIV & Fresh & Dry \\
\hline Sample I & 2.07 & 2.05 \\
Sample 2 & 1.9 & 1.85 \\
Sample 3 & 2.05 & 1.89 \\
Sample 4 & 1.86 & 2 \\
\hline
\end{tabular}

However there were no any significant differences on the above result, which indicated that the samples are free from proteins, phenol or other contaminants that usually absorb higher at A280. Generally the modified protocol produces enough quality and quantity of DNA that produces enough Template DNA of $\sim 530 \mathrm{bp}$ PCR product.

\section{Acknowledgments}

None.

\section{Conflicts of interest}

The author declares there are no conflicts of interest.

\section{References}

1. Joachim H. Physic nut; Jatropha curcas L. International Plant Genetics Resources Institute. 1996.

2. Reinhard KH. Use of Jatropha curcas oil as row marterial and fuel; an integrated approach to create income and supply energy for rural development. Jatropha Syatem. 2000.

3. Martin G, Mayeux A. Reflexions surles cultures oleagineuses energetiques. II- Le Pourghere (Jatropha curcas L.) : un carburant possible. Oleagineux. 1984;39(5):283-287.

4. Dehgan B, Webster GL. Morphology and infrageneric relationships of the genus Jatropha (Euphobeiceae). 1979.

5. Olaniyi A. Jatropha Promotion in Nigeria: The green gold, Centre for Jatropha Promotion \& Biofuel, Nigeria. 2006.

6. Brown JK, Idiris AM, Bird J. Jatropha gassipiifolia from Puerto Rico. Journal of Phytopathology. 1999;90:122.

7. Rangawamy KT, KS Shankarappa, DS Aswatha Narayana, et al. Natural Occurrence of a Mosaic virus disease in India. Current Science. 2006;91(5):584-586.

8. Centre for Jatropha Promotion. 2007.

9. Lodhi MA, YEG, Weeden NF, et al. A simple and efficient method for DNA extraction from grapevine cultivars and vitis species. Plant Mol Bio. 1994;12(1):6-13. 